\title{
Voice, Transitivity and Tense/Aspect: Directionality of Change in Indo-European (Evidence from Greek and Vedic)
}

\author{
Nikolaos Lavidas and Leonid Kulikov
}

\begin{abstract}
The aim of this article is to examine the directionality of change in Voice in relation to Tense/Aspect, foremost based on evidence from Greek as well as additional evidence from Early Vedic. Starting with the hypothesis that in (standard) Proto-Indo-European a number of innovations resulted in the introduction of some elements of the Perfect-Stative inflection into the Present (cf. Kulikov \& Lavidas 2013), we study the directionality of change in Voice. We show that the original relationship between Tense/ Aspect and Voice determines the directionality of change in Voice in Greek. Basing our study on the analysis of Vedic active Perfects that are intransitive and belong with middle Presents, we claim that this initial relationship between Voice and Tense/ Aspect can be reconstructed on the basis of some tendencies and changes found in several Indo-European dialects, in particular in Greek forms. We also argue that the relationship between Tense/Aspect and Voice in the diachrony of Greek depends on the new features acquired by the voice morphology as well as on the development of the categories Tense and Aspect.
\end{abstract}

The hypothesis that the Indo-European (IE) categories Middle and Perfect are historically related (and probably originate in one single proto-category) goes back as far as Kuryłowicz (1932) and Stang (1932). This hypothesis is based on the fact that the middle voice and the active Perfect endings share a number of characteristics in ancient IE languages (for further discussion see, for instance, Di Giovine 1990-1996; Kulikov 1999). The category of Stative has also been appended to the Middle and Perfect relationship (Oettinger 1976; Jasanoff 1978; Di Giovine 1990-1996; Kümmel 1996; Gotō 1997; for the relationship between Perfect, Stative and Middle in PIE, see also Kuryłowicz 1964; Kortlandt 1979, 1981). Kulikov (1999) has drawn attention to a particular type of relationship 
between Tense and Transitivity that can be called "split causativity." This tendency, observable for some verbs in Vedic and Homeric Greek, characterizes basic correlations between the tense oppositions (Present/Perfect), on the one hand, and Transitivity of the verbal form, on the other:

\section{Verbal formations of the Present system : transitive-causative Verbal formations of the Perfect system : intransitive}

This tendency could result in a number of secondary (and, at first glance, inexplicable) uses of some forms, such as, for example, the use of Perfect forms in the function of intransitive Present forms, as in the case of the early Vedic "Perfecto-Presents." This formation includes not only the handbook example véda 's/he knows', but also a less studied group of forms with a long reduplication syllable, which are mostly or exclusively employed with present resultative (stative) meanings; e.g., jar 'become awake' - jāgấra 'is awake' $(\leftarrow$ 'has awoken'), dì 'shine' - dīdấya 'shines'. Notice that a few such Perfects sporadically use the long reduplication to emphasize both the present (stative) meaning as opposed to the preterital (pret.) usages of the Perfect of the same root and their prevailingly intransitive syntax; cf. tan 'stretch': tatâna 'has stretched (pret.), stretches (pres.)', tätấna 'stretches (pres.)' (cf. ex. (2) below) or vrot 'turn': vavárta 'has turned (pret.), turns (pres.)' vā várta 'turns (pres.)'. See Delbrück (1888: 297); Kümmel (200o: 21-22, with fn. 10, 191-194, 208-211, 227230, 462-469 et passim); Kulikov (2005: 439). Most importantly, in this case we are dealing with, in fact, the embryo of a separate tense category "perfectopresent" (Kulikov 2005: 450, note 18).

Given this assumption (cf. Kulikov \& Lavidas 2013), the active/middle opposition would have been not relevant to Perfect forms in early Proto-IndoEuropean (PIE) (Figure 7.1). Accordingly, leaving aside the difficult issue of the chronological localization of the emergence of the PIE aorist, we can tentatively present the structure of the early PIE verbal system as stage I in the scheme below. ${ }^{1}$ In (standard) PIE, a number of innovations (resulting from a contamination and/or analogical rebuilding of endings belonging to different sets) resulted in the introduction of some elements of the Perfect-Stative inflection into the Present (Kortlandt 1979). These forms must have retained the

1 With regard to the Aorist, there are some reasons to believe that the Aorist is a more recent addition to the early PIE verbal system, probably going back to some nominal formations (Kortlandt 2009, 2010). Yet, much remains unclear about the exact status and origin of this tense form in the PIE verbal system. However, this issue goes beyond the scope of the present article and cannot be discussed here at length. 


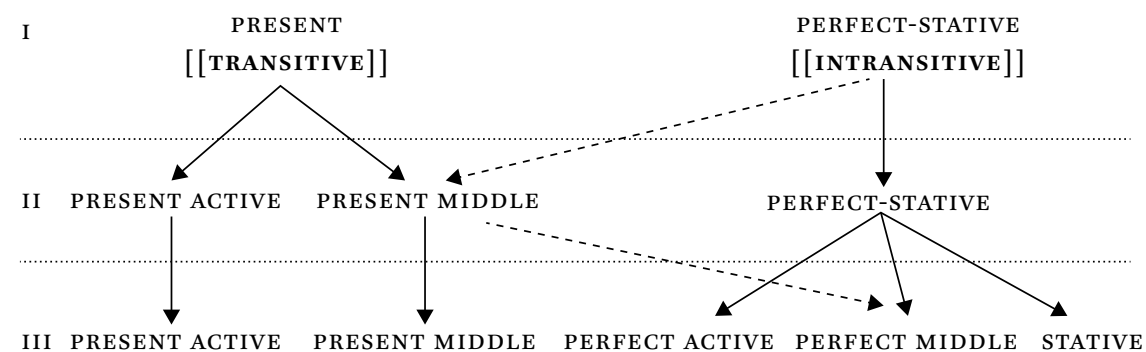

FIGURE 7.1 The emergence and development of the middle in IE (adopted from Kulikov 2006). Splits denote the reanalysis of a category (for instance, the reanalysis of the Present, that was identified with the transitive patterns, into two types of Present, active and middle Present); Lines express the development of a category, and dotted lines innovation [contamination and/or analogical rebuilding of endings belonging to different sets] with the extension of a category (for instance, with the introduction of some elements of the Perfect-Stative inflection into the Present).

functional connection with the statives that were associated with intransitive syntax. Notice that this feature of the Perfect-Stative fits well with the recent analysis by Dahl (2010) of the meaning of the Vedic (and, to some extent, PIE) Perfect as largely based on the resultative semantics. This connection may be one of the mechanisms that had given rise to the middle voice used to mark several intransitive derivations. In some IE dialects (Stage III), the active/ middle distinction was introduced into the Perfect under the influence of the Present (Renou 1925: Ch. 5-8; Jasanoff 1978: 16, 81f.; Kümmel 200o: 94). ${ }^{2}$

The aim of the present study is to show how this original relationship between Transitivity/Voice and Tense determines the directionality of changes in Voice in Greek. Taking as a starting point the analysis of Vedic active Perfects that are used intransitively, and, from the syntactic point of view, can be grouped with middle Presents, we will argue that this initial relationship between Transitivity/ Voice and Tense/Aspect is reflected in Greek in the form of some tendencies and relics. Moreover, we will show that the correlation between Tense/Aspect and Voice/Transitivity triggers the development of some new features of the category of voice as well as a number of new developments of the categories Tense and Aspect. In the following section, we provide further evidence for

2 We thank the reviewer for the remark that the contrast between the more ancient transitive Presents and intransitive Perfects is also represented in the distinction between Greek intransitive Perfects, which are more ancient, and transitive new formations. Cf., for instance, pépeika (persuade:PF.1SG) 'I have persuaded (somebody)' vs. pépoitha (persuade:PF.1SG) 'I trust, I am persuaded' (Luraghi, Pompei \& Skopeteas 2005). 
the correlation between Tense/Aspect and Transitivity/Voice, which is the basis of our hypothesis. Section 3.1 describes the status of Tense/Aspect in Homeric Greek as well as the changes in this category in Classical and Koine Greek. In Section 3.2, the historical relationship between Transitivity/Voice and Tense/ Aspect is presented through a discussion of their parallel development and directionality of changes in Greek. Section 4 summarizes the main conclusions of this study.

\section{Correlations between Tense/Aspect and Transitivity/Voice in Ancient Indo-European: Preliminary Remarks}

The prevailing intransitivity of the Perfect forms in Homeric Greek was repeatedly observed in historical grammars and studies of the Greek verb (Wackernagel 1904; Chantraine 1927; Bader 1972; Kulikov 1999), cf. (1a) vs. (1b). The same holds true for the observation that active Perfects are intransitive and belong with middle Presents (see Kulikov 1999). ${ }^{3}$

a. pántas mén $r h^{\prime} \quad$ élpei

all:ACC.PL PTC PTC hope:ACT.PRS.3SG

'She holds out hope to all.' (lit. 'makes all hope') (Hom. Od. 2.91; 8th c. BC)

b. mál' éolpas eni phresí

very hope:ACT.PF.2SG in mind:DAT.SG

'Certainly, you hope in your mind ...' (Hom. Il. 21.583; 8th c. BC)

In Vedic, a number of verbs such as tan 'stretch' or $u k s s / v a k s ̣$ 'grow, increase' display a comparable distribution of syntactic patterns: the forms of the Perfect system mostly appear in intransitive (anticausative) constructions, whereas the corresponding forms of the Present system mainly attest transitive syntax; see Kulikov 1999: 26ff. for details. Cf. (2a) vs. (2b).
$(2)$
a. ahám rudráya
dhánur
á $\quad$ tano-mi
I:NOM Rudra:DAT.SG bow:ACC.SG to
'I stretch the bow for Rudra.' (RV 10.125.6)

3 Cf., for example, Velten (1931: 239, fn. 32): "Active Perfect forms with an intransitive meaning often used as a Present like dédorka 'I see' - occur commonly beside medio-passive Presents $[\ldots]$ the Perfect itself is of durative character and serves as a device of durativation." 
b. dūrát súryo ná śocișāa tatān-a from.afar sun:NOM.sG like flame:INs.SG stretch:PF-3SG.ACT 'From afar [Agni] is/has extended (resultative), like the sun, with [his] flame.' (RV 6.12.1)

The ratio of syntactic patterns (transitive/intransitive) attested with the verb tan 'stretch' which is one of the most instructive examples, is shown in Table 7.1 and 7.2 (adopted from Kulikov 1999): the bigger font used for Vedic forms in Table 7.2 shows that transitive-causative Presents and intransitive Perfects are more common than intransitive Presents and transitive-causative Perfects.

Drawing on such phenomena, we can assume that the initial relationship between Tense/Aspect and Voice is evidenced in the Indo-European dialects in the form of certain (weak) tendencies and archaisms. Furthermore, the Indo-European dialects follow their own path of development both with regard to the features of the new active vs. middle opposition and the relation of Transitivity/Voice to Tense/Aspect. This means that the directionality of change of the hypothesized relationship between Tense/Aspect and Transitivity/Voice depends on the new features (or values) that the voice morphology acquires,

TABLE 7.1 Transitivity and Tense in Vedic: the ratio of transitive/intransitive constructions in the Present and Perfect in the Rgveda

\begin{tabular}{lll}
\hline & Intransitive & Transitive \\
\hline Present & 7 & $\approx 40$ \\
Perfect & $\approx 25$ & $\approx 15$ \\
\hline
\end{tabular}

TABLE 7.2 Transitivity and Tense in Vedic: Predominantly transitive-causative Presents vs. intransitive Perfects ${ }^{a}$

\section{Present}

Perfect

Present indicative Present subjunctive

$\begin{array}{llll}\begin{array}{l}\text { Intransitive } \\ \text { Transitive- }\end{array} & \text { tanóti etc. } & - & \text { tatána etc. } \\ \text { Causative } & \text { tanóti etc. } & \text { tanavāvahai etc. } & \text { tatấna etc. }\end{array}$

a For the sake of simplicity, we do not show in this table other forms of the Present system. 
as well as on the development of Tense/Aspect (and its relation to Voice) in the IE dialects. In the following section, we will examine the nature of the relationship between Tense/Aspect and Transitivity/Voice in Homeric Greek, and we will provide evidence for the directionality of the development of this relationship at the later stages of Greek. We will argue that the PIE relationship between Transitivity/Voice and Tense/Aspect is reflected in Greek in the form of some tendencies, and that the directionality of the change of the relationship between Tense/Aspect and Transitivity/Voice depends on the new features acquired by the voice morphology as well as on the development of the categories Tense and Aspect. As we locate and trace the contribution of the new features to the direction of changes within the linguistic system, we are also able to provide a more adequate and reliable reconstruction of the PIE stage.

The Development of the Hypothesized PIE Relationship between Tense/Aspect and Transitivity/Voice: Correlations between Tense and Transitivity/Voice in Greek

\subsection{Tense and Aspect in Greek}

In this section, we present data from Greek aiming at analyzing the development of the hypothesized PIE relationship between Tense/Aspect and Transitivity/Voice. ${ }^{4}$ The development of this relationship is complex because both Transitivity/Voice and Tense/Aspect follow various paths in different ancient IE dialects. However, the study of changes in the features of Tense/ Aspect and Transitivity/Voice in Greek can reveal many aspects of both the PIE verbal system and the nature of changes in IE languages.

Based mainly on Moser $(2005,2008,2014)$, the main characteristics of the Tense/Aspect system of Homeric Greek can be summarized as follows: The Perfect is often not distinguished from the Present in Homeric Greek and has the same interpretation as the corresponding Present; 5 see (3). Furthermore, the Perfect almost never expresses a resultative meaning in Homeric Greek (on Perfect in Homeric Greek, see also Monro 1891, Schwyzer \& Debrunner 1950 and Chantraine 1953). The Present in Homeric Greek displays greater variation than the Perfect with regard to its interpretations

4 We refer to the following periods of Greek: Homeric Greek: 8th c. BC; Classical Greek: $5^{\text {th }}-3^{\text {rd }}$ c. BC; Hellenistic and Roman/ Koine Greek: 3rd c. BC-4th c. AD; Early Byzantine Greek: $5^{\text {th }}$ 8th c. AD.

5 Schwyzer \& Debrunner (1950: 227) argue that it is (only) the Middle which alternates with the Perfect. 
and functions, but verbs denoting achievements are rare with the Present. Two verbs with the same function differing in lexical aspect, or actionality (Aktionsart) - accomplishment vs. activity, for instance - are not found in the same tense, but the accomplishment is attested in the Aorist and the activity in the Present (kálupsen - anapálletai in Ex. 4). ${ }^{6}$

(3) epeì polù boúlomai autèn oíkoi because much want:PRS.1SG 3SG.F.ACC.SG house:DAT.SG ékhein. Kaì gár rha Klutaimnèstrēs probéboula have:INF and PTC PTC Klytemnestra:GEN.SG prefer:PF.1SG 'Because I very much want to have her at home. For I prefer her to Klytemnestra.' (Hom. Il. 1.112-113; 8th c. BC - Moser 2008) ${ }^{7}$

(4) hos d' hoth' hupò phrikòs Boréo as PTC when by gust:GEN.SG north.wind:GEN.sG anapálletai ikhthùs thín' en shudder:PRS.3SG fish:NOM.SG sand:DAT.SG in phukióenti, mélan-dé he seaweed.covered:DAT.SG black:ACC.SG-and 3SG.M.ACC.SG kûma kálupsen hòs plēgeis wave:ACC.SG cover:AOR.3SG thus hit:AOR.PRT.NOM.SG anépalt'(o) shudder:AOR.3SG

'As when the fish shudders in a gust of the north wind in the seaweedcovered sandy sea and the black wave covers it, thus did he shudder when hit.' (Hom. Il. 23.692-694; 8th c. BC - Moser 2008)

Verbs in the Aorist in Homeric Greek can appear without the past tense augment, which is obligatory in Classical Greek (see below). Moreover, many verbs in Homeric Greek are attested in only one of the stems, either Present, Aorist, or Perfect. According to Moser (2014), Homeric dictionaries supply the entire paradigm but point out that some forms are not attested in Homeric

6 kálupsen here denotes the event triggering the anapálletai-event.

7 Latacz (2003) considers probéboula to be a resultative: “Ganz recht, ich hab' sie Klytaimestra vorgezogen." 
TABLE 7.3 The number of verbs (types) that appear in Present, Aorist, and Perfect in Homer's Iliad $^{\mathrm{a}}$

\begin{tabular}{llll}
\hline & $\begin{array}{l}\text { Present } \\
(3 \mathrm{sg}-\text { indicative })\end{array}$ & $\begin{array}{l}\text { Aorist } \\
(3 \mathrm{sg}-\text { indicative })\end{array}$ & $\begin{array}{l}\text { Perfect } \\
(3 \mathrm{sg}-\text { indicative })\end{array}$ \\
\hline $\begin{array}{l}\text { Number of verbs } \\
(\text { types })\end{array}$ & $34.78 \%$ & $54.62 \%$ & $10.60 \%$ \\
$(1472)$ & $(512)$ & $(804)$ & $(156)$ \\
\hline
\end{tabular}

a The tables are based on searches in electronic corpora of Homeric, Classical, and Koine Greek: Proiel (http://www.tekstlab.uio.no:30oo/), Perseus Digital Library (http://www .perseus.tufts.edu) and Perseus under Philologic (http://perseus.uchicago.edu/), The Homer Chicago (http://digital.library.northwestern.edu/homer/), and TLG online (http://www.tlg .uci.edu/).

Greek. ${ }^{8}$ In Table 7.3, we present a corpus study that we conducted with regard to the types (lemmas) that appear in the Present, Aorist, and Perfect in Homer. This comparison is based on the hypothesis that the Present-Aorist-Perfect tripartite opposition in Homeric Greek was based on Aktionsart and denoted duration/ non-terminativity, instantaneity/ terminativity, and stativity, respectively (see below). Table 7.3 shows that there is a statistically significant difference between the number of types (lemmas) that appear in the different tenses in Homer.

Moser $(2005,2008,2014)$ claims that the morphological tense oppositions in Ancient (Homeric and Classical) Greek express the opposition between the stative and dynamic interpretations. In later stages of the language, this dynamic interpretation is further differentiated with respect to telicity and duration. Cf. Moser (2014: 76) and Figure 7.2:

8 With regard to the counter-examples, cf. Moser (2014: 76-77):

"This is not to say that Homeric Greek presents a homogeneous picture of an Aktionsart-based system. On the contrary, the aspectual system is already well-established, as shown in Napoli (2006). The epic, however, is a multi-layered text, not only with elements from different dialects but also with elements from different periods. At the time the Iliad and the Odyssey were written down, they had already been circulating as oral poetry for centuries. Due to the formulaic nature of oral epics, some of the earlier linguistic characteristics were preserved (see, for instance, Horrocks 2007). It is those elements differing from the norm that can point us to older stages in the history of the language." 
All this leads to a conclusion similar to that of Sihler $(1995,445)$, according to whom the Homeric situation - in conjunction with the data from other Indo-European languages - suggests that, in earlier stages, the Present-Aorist-Perfect tripartite opposition was based on Aktionsart, expressing respectively duration/ nonterminativity, instantaneity/terminativity, and stativity.

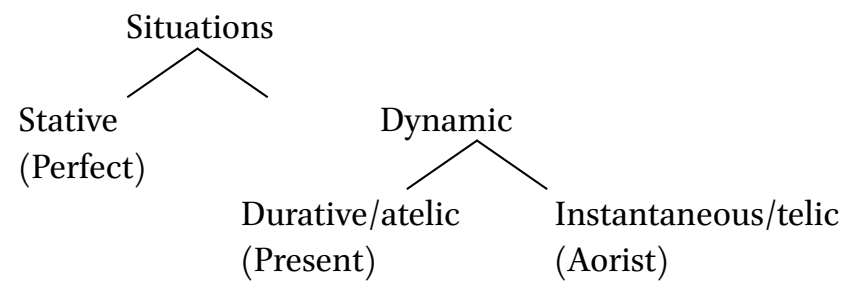

FIGURE 7.2 The system of Tenses in Homeric Greek. From Moser (2014: 76)

TABLE 7.4 The ratio of verbs (types) in the active vs. mediopassive Perfect in Homer (Iliad and Odyssey)

Perfect active - Homer, Iliad

Perfect active - Homer Odyssey

Perfect active - Homer (total)

Perfect mediopassive - Homer, Iliad

Perfect mediopassive - Homer Odyssey

Perfect mediopassive - Homer (total)

$$
\begin{aligned}
& (119 / 252) 47.22 \% \\
& (83 / 226) 36.73 \% \\
& (202 / 478) 42.26 \% \\
& (133 / 252) 52.78 \% \\
& (143 / 226) 63.27 \% \\
& (276 / 478) 57.74 \%
\end{aligned}
$$

Given the systematic correlation between Tense/Aspect and Transitivity/Voice and the correlation between Perfect and Middle (see Section 2 and Table 7.4), we can hypothesize a parallel directionality for the development in Tense/ Aspect and Transitivity/Voice in Greek.

Before proceeding to the status of Voice in Homeric Greek and the analysis of its relation to Aktionsart and Tense/Aspect, we refer here to the development of Tense/Aspect in Greek. The aim is to provide a basis for a comparison to the development of Voice in Greek. Note that it is beyond the scope of this study to analyze the characteristics and development of Tense/Aspect in all periods of Greek. We focus on the evidence available from Homeric Greek, as well as changes attested in Classical and Koine Greek, to track the directionality of the relevant changes.

In Classical Greek, all verbs can have forms based on the Perfect, Present, and Aorist stem. Uses that show a dependence on Aktionsart in Classical Greek 
are absent from Koine Greek (Moser 2008). ${ }^{9,10}$ In Classical Greek, the Future forms still do not express the perfective-imperfective opposition, which will become available in Koine Greek with the periphrastic formation of the Future. However, the uses of the Perfect and Aorist as Presents have been lost in Classical Greek - but with some archaic exceptions (for instance, péphuka 'be by nature'); in addition, the past augment is obligatorily used in the Aorist forms and the Perfect acquires a resultative interpretation.

Koine Greek (and Early Byzantine Greek) demonstrate the most significant changes in the Tense/Aspect system (and we will observe that the same holds true for the relationship between Tense/Aspect and Voice as well). In Koine Greek, the synthetic Perfect and Future are replaced with periphrastic forms, see Blass, Debrunner \& Rehkopf (1975 [1984]: §§ 340-356), Moser (1988). All new periphrastic constructions express the opposition of perfectivenonperfective, creating the new status of the Tense/Aspect system: verbal forms are linked to the aspect (grammatical aspect/outer aspect) and not to the Aktionsart.

To summarize the discussion above, (a) in Homeric Greek, the morphological tense oppositions show certain relationships with Aktionsart (as archaisms), and (b) in Koine Greek, we observe several features of the innovative relation of the verbal forms to the (grammatical) aspect. In Section 3.2, we will show that Voice in Greek changes in a similar way to the morphological tense oppositions (which were linked to Aktionsart/lexical aspect in Homeric Greek but to (grammatical) aspect in Koine Greek). We will show that the mediopassive morphology in Homeric Greek was linked to the absorption of any argument (agent, cause, benefactive), but changed into an intransitivity marker, blocking the presence of an object in the accusative, in later stages (Lavidas 2012; Lavidas et al. 2012). This means that intransitivity was not rigidly connected with the (mediopassive) voice in Homeric Greek. This is particularly evident in the case of active forms with passive interpretation or mediopassive

9 Cf. van Gelderen (2004: 203ff), who argues for a similar change in the history of English where the setting of a parameter is switched from having (inner/ lexical) aspect as unmarked to tense as unmarked.

10 Cf. Moser (2014: 77):

"In Classical Greek, the picture has changed quite dramatically. Verbs now possess full paradigms, with instances of practically every form attested in the very large corpus of texts. These forms are used with considerably greater freedom in order to express the speaker's vantage point, i.e., grammatical aspect. But aspect has not gained complete independence from Aktionsart: the latter still plays an important role in determining choice." 
forms that were transitive and could take a direct object in the accusative, with an autobenefactive interpretation (see below).

\subsection{Transitivity/Voice and Tense/Aspect in Greek}

The relation of Voice to Tense/Aspect is evident in Homeric Greek. Homeric Greek has a system of distinctions between three voices: active, middle, and passive, but the middle and the passive morphology are distinguished only in the Future and Aorist (Aorist stem); Table 7.5.

TABLE 7.5 Middle and passive endings in the Future and Aorist (Aorist stem)

\begin{tabular}{|c|c|c|c|}
\hline & Future & Aorist & \\
\hline Middle endings & -somai & -samēn & \\
\hline Passive endings & -thēe-somai & $-(t h) \bar{e}-n$ & -thè-samēn \\
\hline
\end{tabular}

From a purely morphological perspective, an additional non-active morpheme, -the , can be distinguished in the passive type of the Future and Aorist (Aorist stem): lu-thế-somai (unbind/release-PASS-MP.FUT.1SG) vs. $e$-lú-thēe-n $\boldsymbol{n}^{11}$ (AOR-unbind/release-PASS-1SG, cf. Chantraine 1953, 1961). In the Future, the morphemes -the- and -omai express the non-active, whereas in the Aorist, only the morpheme -thē- expresses the non-active. Moreover, the suffix $-\bar{e}-$ of the Aorist (as in ekseplág-e-en 'I was struck with terror or amazement') should have started as an Aorist suffix for active verbs of the -mi-conjugation (- $\bar{e}$ - started as an Indo-European suffix of stative verbs). We focus here on the directionality of change in its functions. However, at a second stage, $-\bar{e}$ was used for encoding intransitive derivatives (reflexives, anticausatives - but not passive) with verbs that take active endings and, at a third stage, as a non-active (reflexive, anticausative, and passive) suffix (although it was less frequent in the passive function than -thē-, cf. Allan 2003); see (5).

11 Humbert (1945) has argued that the new formation of the passive Aorist with -thē- has been completed in Homer, that the passive Future with -thēsomai, unknown in Homer and Herodotus, is not in evidence before Aeschylus. The passive Future was formed on the basis of the Aorist. 
The suffix $-\bar{e}$ - is used mainly in reflexive and anticausative constructions in Homer: of the 22 instances mentioned by Delbrück (1897), only two have a purely passive interpretation (eplêgēn 'I was smitten' / etúpèn 'I was beaten'); see (6). All of the remaining examples are not passive; many, in fact, denote spontaneous change-of-state (pagênai 'become solid/stiffen', ragênai 'break', tmagênai 'be po divided') as is shown in (7). Hence, there appears to be a connection between the early suffix $-\bar{e}$ - and anticausativity. ${ }^{12}$
(5) ekséplēksa (transitive)
I ekseplág-ēe- $n$ (intransitive)
'I struck with terror or amazement.'
'I was struck with terror or amazement.'
(6) hélkea pánta mémuken
hóss'
wounds:NOM all:NOM heal:ACT.PF.3SG
which:NOM
etúpē

strike:PASS.AOR.3SG

'All his wounds have been closed up where he was struck.' (Hom. Il. 24. $420-421 ; 8$ th c. BC)

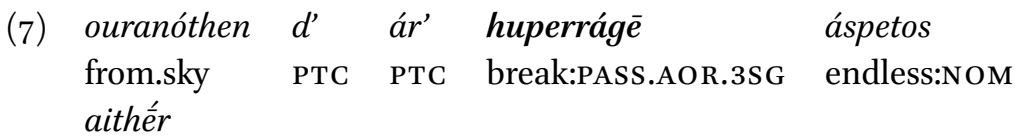

bright.air:NOM

'And from heaven breaks open the infinite air.' (Hom. Il. 16.300; 8th c. BC)

Homeric Greek verbs with the morpheme -the- are mainly reflexives, anticausatives, and, in rarer cases, passives. Grosse (1889) refers to only 30 examples with a purely passive interpretation (ktathênai acquire:PASS.AOR.INF) from the 129 examples that he notes (e.g., intransitive: agerthênai gather:PAss. AOR.INF). Cf. also relevant tables in the detailed study of the middle and passive in Homeric and Classical Greek by Allan (2003), as well as our discussion of Allan (2003) in Kulikov \& Lavidas (2017).

Allan (2003) has shown that passive Aorists in both -the- and $-\bar{e}$ - have exactly the same interpretations: passive, spontaneous process, mental process, and

\footnotetext{
12 This is not an absolute claim because, in some cases, middle forms of the same verbs in the Present may indicate change-of-state. We thank the reviewer for the discussion of this issue.
} 
TABLE 7.6 Meanings of root and thematic Aorists in Homer (Allan 2003)

\section{a. Root Aorists:}

Passive

Spontaneous process

Mental process

Body motion

Collective motion

Speech act

Indirect reflexive

b. Thematic Aorists:

Passive

Spontaneous process

Mental process

Body motion

Collective motion

Perception

Speech act

Indirect reflexive

\author{
éktato 'was killed' \\ phthímēn 'perished' \\ étlēn 'endured, dared' \\ âlto 'jumped' \\ ksúmblèto 'met with' \\ eûkto 'boasted, prayed' \\ étheto 'put sth for oneself' \\ eskhómēn 'was held' \\ òlómèn 'perished' \\ elathómēn 'forgot' \\ etrapómēn 'turned' \\ ēgrómetha 'gathered' \\ èisthómēn 'perceived' \\ èrómēn 'asked' \\ ègagómēn 'led away for myself'
}

(collective and body) motion. According to Allan's results, the sigmatic middle Aorist is not attested with a spontaneous or a passive meaning..$^{13}$ Reflexives, however, can be marked with the sigmatic middle Aorist. See also Table 7.6, from Allan, which presents the meanings of root and thematic Aorists in Homer. With regard to Future, according to Allan, the passive Future has a generic/non-iterative/perfective meaning (as demonstrated mainly with Classical Greek examples by Allan).

As far as the distribution of active and mediopassive morphology in Homeric Greek is concerned, mediopassive morphology is considered the marked form in relation to active voice (for instance, by Bakker 1994: 24). The middle morphology is not identified with one construction (reflexive or anticausative). The middle morphology can be used in passive constructions (with the presence or absence of an agent-PP). Nor is the passive type identified with the passive construction. The passive type can be used productively in intransitive non-passive constructions - for instance with psych-verbs - in anticausative constructions. We suppose, therefore, that it is concerned with two different

13 We should note that Homeric and Classical Greek have three different morphological types of middle Aorist (root, thematic, and sigmatic) and two morphological types of passive Aorist (in $-\bar{e}-$ and - the - -). 
morphological forms of the same non-active category, which are used alternately. The mediopassive morphology is also frequently used in transitive constructions and adds the meaning that the result of the verb action concerns the subject: tithemai nómon (place:MP.PRS.1SG law:ACC) 'pass a law in my own interests' / 'pass myself a law' - in contrast to the active tithēmi (place:ACT. PRS.1SG) 'pass a law'. In other words, the mediopassive morphology leads to absorption of the benefactive (or, it expresses indirect reflexivity, in traditional terminology). Moreover, the mediopassive verbs in reflexive constructions can take a direct object in the accusative in Homeric Greek, if the object-goal is directly related to the subject; see (8). ${ }^{14}$

loúomai 'wash'

egkalúptomai 'veil/wrap up'

peribállomai 'throw round or over oneself/put on' peritíthemai 'place or put round/put on'

In Homeric Greek (see also above), an agent in PP or in the dative could appear in constructions with active verbs and an undergoer(theme)-argument as the subject. This concerns a typical instance of a (lexical) passive construction, but with verbs bearing active morphology (Jankuhn 1969). However, in Homeric Greek, the first signs of productive use of mediopassive morphology in passive constructions are also attested.

A corpus study clearly shows that the distribution of voice (active vs. middle vs. passive) heavily depends on Tense/Aspect; see Table 7.7. A chi-square was performed to assess the relationship between the voice morphology and the different tenses. The results of the Pearson chi-square analyses were statistically

14 The mediopassive voice morphology is also used in transitive constructions with deponents (for an analysis of the deponents in diachrony, cf. Lavidas \& Papangeli 2006). We do not examine deponents in this study because these verbs do not change morphology (they always have non-active morphology) for purposes of transitivity alternations.
(1) egò̀ Kleinían hédion
mèn theômai
ऐ̀ $\quad$ tâlla

I:NOM Cleinias:ACC more.pleasantly PTC gaze:MP.PRS.1SG than the.other:ACC

pánta

all:ACC

I would rather gaze at Cleinias than at all the other (beautiful objects in the world).' (X. Smp. 4.12; $5^{\text {th }}-4^{\text {th }}$ c. BC) 
TABLE 7.7 Tense/Aspect and Voice in Homer: Percentage of active vs. mediopassive forms in the different tenses/aspects ${ }^{\mathrm{a}}$

\begin{tabular}{lccc}
\hline & Active & Middle (Mediopassive) & Passive \\
\hline Present & $85.16 \%$ & $14.84 \%$ & \\
(3sg Indicative) & $(1245 / 1462)$ & $(217 / 1462)$ & $4.46 \%$ \\
Aorist & $77.07 \%$ & $18.47 \%$ & $(285 / 6393)$ \\
(3sg Indicative) & $(4927 / 6393)$ & $(1181 / 6393)$ & \\
& & middle+passive= & \\
Imperfect & & $22.93 \%$ & \\
(3sg Indicative) & $(3331 / 4396)$ & $24.23 \%$ & \\
Perfect & $69.19 \%$ & $(1065 / 4396)$ & \\
(3sg Indicative) & $(238 / 344)$ & $30.81 \%$ & \\
Pluperfect & $60.70 \%$ & $(106 / 344)$ & \\
(3sg Indicative) & $(227 / 374)$ & $39 \cdot 30 \%$ & \\
Future & $40.72 \%$ & $(147 / 374)$ & \\
(3sg Indicative) & $(191 / 469)$ & $59.28 \%$ & \\
Future Perfect & $13 \cdot 33 \%$ & $(278 / 469)$ & \\
(3sg Indicative) & $(2 / 15)$ & $86.67 \%$ & \\
\hline
\end{tabular}

a The verbs included in these corpus studies (Tables 7.7, 7.8 and 7.9) are all in the 3 rd singular and indicative, to avoid effects in the results by person, number, and mood, or by the nature of participles and infinitives.

b With regard to all Future forms, and not only 3sg Indicative, there is only one passive Future: migếsesthai mix:FUT.PASS.INF.

significant for the comparison between the Perfect and all other tenses ${ }^{15}$ and for the comparison between the Future and all other tenses. ${ }^{16}$

This means that the ratios of active vs. middle/passive morphology are not similar for all tenses/aspects, but are significantly correlated with the type of Aktionsart that is expressed by each of the tense/aspects. Accordingly,

15 vs. Present: $\chi^{2}=48.368$, $\mathrm{p}<.001$, with an effect size of $\varphi=.164$, which is a small effect size; vs. Imperfect: $\chi^{2}=7.442, p=.006$, with an effect size of $\varphi=.040$, which is a small effect size; vs. Aorist: $\chi^{2}=11.338, \mathrm{p}=.001$, with an effect size of $\varphi=.041$, which is a small effect size; vs. Future: $\chi^{2}=64.497, \mathrm{p}<.001$, with an effect size of $\varphi=.282$, which is a medium effect size; vs. Pluperfect: $\chi^{2}=5.661, \mathrm{p}=.017$, with an effect size of $\varphi=.089$, which is a small effect size.

16 vs. Present: $\chi^{2}=367.741, \mathrm{p}<.001$, with an effect size of $\varphi=.436$, which is a large effect size; vs. Imperfect: $\chi^{2}=260.487, \mathrm{p}<.001$, with an effect size of $\varphi=.231$, which is a medium effect size; vs. Aorist: $\chi^{2}=304.467, \mathrm{p}<.001$, with an effect size of $\varphi=.211$, which is a medium effect size; vs. Future Perfect: $\chi^{2}=4.549, p=.033$, with an effect size of $\varphi=.097$, which is a small effect size. 
more Future forms (59.28\%) appear with middle morphology than with active. The Perfect (and Pluperfect and mainly Future Perfect) show more types with middle morphology than the other tenses do (Present, Imperfect, Aorist) - even though the middle Perfect forms do not constitute the majority of Perfect forms.

Changes in Voice go in parallel with the development of Tense/Aspect in Greek: Koine Greek attests an entirely new system of Voice. This is represented in the differences in the distribution of Voice and Tense/Aspect in Classical (Table 7.8) and Koine Greek (Table 7.9), which can be compared with Homeric Greek (Table 7.7). The purpose of this corpus study is to present data and evidence on the change in the distribution of voice morphology among tenses/aspects. The significance of the study is evident in testing the quantitative representation of a possible relationship between tense/aspect and voice.

TABLE 7.8 Tense/Aspect and Voice in Classical Greek (Plato's works): Percentage of active vs. mediopassive forms in the different tenses/aspects

\begin{tabular}{lccc}
\hline & Active & Middle (Mediopassive) & Passive \\
\hline Imperfect & $95 \cdot 38 \%$ & $4.62 \%$ & \\
(3sg Indicative) & $(4769 / 5000)$ & $(231 / 5000)$ \\
Present & $86.81 \%$ & $13.19 \%$ & \\
(3sg Indicative) & $(10883 / 12537)$ & $(1654 / 12537)$ & \\
Perfect & $77.22 \%$ & $22.78 \%$ & $20.34 \%$ \\
(3sg Indicative) & $(1519 / 1967)$ & $(448 / 1967)$ & $(369 / 1814)$ \\
Pluperfect & $65.87 \%$ & $34.13 \%$ & \\
(3sg Indicative) & $(83 / 126)$ & $(43 / 126)$ & \\
Aorist & $58.93 \%$ & $20.73 \%$ & $4.35 \%$ \\
(3sg Indicative) & $(1069 / 1814)$ & $(376 / 1814)$ & $(71 / 1634)$ \\
& & middle+passive= & \\
Future & & $41.07 \%$ & \\
(3sg Indicative) & $(729 / 1634)$ & $51.04 \%$ & \\
& & $(834 / 1634)$ & \\
Future Perfect & $9.09 \%$ & middle+passive= & \\
(3sg Indicative) & $(2 / 22)$ & $55.39 \%$ & \\
\hline
\end{tabular}


Between Classical and Koine Greek, the tables demonstrate an increase of the active forms in the Present, Imperfect, and Pluperfect, but an increase of the mediopassive forms in the Aorist and Perfect. The results of the Pearson chi-square analyses were statistically significant for the comparison between the distribution of voice morphology in (a) the Present (Present in Classical Greek vs. Present in Koine Greek); ${ }^{17}$ (b) the Imperfect (Imperfect in Classical Greek vs. Imperfect in Koine Greek); ${ }^{18}$ (c) the Aorist (Aorist in Classical Greek vs. Aorist in Koine Greek);19 and (d) the Perfect (Perfect in Classical Greek vs. Perfect in Koine Greek). ${ }^{20}$ Voice morphology in the Future (and Future Perfect for Homeric and Classical Greek) in the different periods shows no statistically significant differences.

TABLE 7.9 Tense/Aspect and Voice in the New Testament (Koine Greek): Percentage of active vs. mediopassive forms in the different tenses/aspects

\begin{tabular}{lccc}
\hline & Active & Middle (Mediopassive) & Passive \\
\hline Imperfect & $93.22 \%$ & $6.78 \%$ & \\
(3sg Indicative) & $(893 / 958)$ & $(65 / 958)$ & \\
Present & $90.99 \%$ & $9.01 \%$ & \\
(3sg Indicative) & $(2251 / 2474)$ & $(223 / 2474)$ & \\
Pluperfect & $85 \cdot 71 \%$ & $14.29 \%$ & $(514 / 3476)$ \\
(3sg Indicative) & $(36 / 42)$ & $(6 / 42)$ & \\
Aorist & $72.64 \%$ & $12.57 \%$ & \\
(3sg Indicative) & $(2525 / 3476)$ & $(437 / 3476)$ & \\
& & middle+passive $=$ & \\
Perfect & & $27,36 \%$ & \\
(3sg Indicative) & $(201 / 367)$ & $45.23 \%$ & \\
Future & $48.66 \%$ & $(166 / 367)$ & $(178 / 748)$ \\
(3sg Indicative) & $(364 / 748)$ & $27.54 \%$ & \\
& & $(206 / 748)$ & \\
Future Perfect & & $51.34 \%$ & \\
(3sg Indicative) & $(0)$ & $(0)$ & \\
\hline
\end{tabular}

\footnotetext{
$17 \quad \chi^{2}=32.986, \mathrm{p}<.001$, with an effect size of $\varphi=.047$, which is a small effect size.

$18 \chi^{2}=7.981, \mathrm{p}=.005$, with an effect size of $\varphi=.037$, which is a small effect size.

$19 \chi^{2}=102.886, \mathrm{p}<.001$, with an effect size of $\varphi=.139$, which is a small effect size.

$20 \quad \chi^{2}=80.451, \mathrm{p}<.001$, with an effect size of $\varphi=.186$, which is a small effect size.
} 
Tables 7.10a-c show the distribution of active, middle, and passive forms according to Tense/Aspect. Active forms are more frequently attested in the Aorist in Homeric Greek, but this picture changes in Classical and Koine (New Testament) Greek, where both Present and Aorist are very frequent with active morphology. With regard to the middle and passive morphology, forms in the Aorist present a decrease (whereas the frequency of the mediopassive in the Present increases).

The frequency of forms (regardless of voice morphology) in the Present increases after Homer, but the ratio between active and mediopassive Presents remains stable. The Perfect has a similar ratio of active and mediopassive in Homeric Greek, but the frequency of Perfect forms becomes higher for the mediopassive than active morphology in the following periods. No statistically significant differences are observed either for Pluperfect or for Future Perfect. A chi-square was performed to assess the relationship between the distribution of tenses in the active/mediopassive voice and different periods. The results of the Pearson chi-square analyses show that there is a change in the distribution of tenses and voice morphology, but that change is not statistically significant. ${ }^{21}$

TABLE 7.10A Tense/Aspect and Voice in Homer: Percentage of use of the different tenses/ aspects with the different voice morphologies [m: middle / p: passive]

\begin{tabular}{|c|c|c|c|c|c|c|c|c|}
\hline & $\begin{array}{l}\text { Present } \\
\left(3^{s g}\right. \\
\text { Indicative) }\end{array}$ & $\begin{array}{l}\text { Imperfect } \\
\text { (3sg } \\
\text { Indicative) }\end{array}$ & $\begin{array}{l}\text { Aorist } \\
\text { (3sg } \\
\text { Indicative) }\end{array}$ & $\begin{array}{l}\text { Future } \\
\text { (3sg } \\
\text { Indicative) }\end{array}$ & $\begin{array}{l}\text { Perfect } \\
\text { (3sg } \\
\text { Indicative) }\end{array}$ & $\begin{array}{l}\text { Pluperfect } \\
\text { (3sg } \\
\text { Indicative) }\end{array}$ & $\begin{array}{l}\text { Future } \\
\text { Perfect } \\
\text { (3sg } \\
\text { Indicative) }\end{array}$ & Total \\
\hline Active & $\begin{array}{l}12.25 \% \\
(1245)\end{array}$ & $\begin{array}{l}32.78 \% \\
(3331)\end{array}$ & $\begin{array}{l}48.49 \% \\
(4927)\end{array}$ & $\begin{array}{l}1.88 \% \\
(191)\end{array}$ & $\begin{array}{l}2.34 \% \\
(238)\end{array}$ & $\begin{array}{l}2.23 \% \\
(227)\end{array}$ & $\begin{array}{l}0.02 \% \\
(2)\end{array}$ & $10161(100 \%)$ \\
\hline $\begin{array}{l}\text { Middle } \\
\text { (Medio- }\end{array}$ & $\begin{array}{l}7.22 \% \\
(217)\end{array}$ & $\begin{array}{l}35 \cdot 42 \% \\
(1065)\end{array}$ & $\begin{array}{l}39.28 \% \\
(1181)\end{array}$ & $\begin{array}{l}9.25 \% \\
(278)\end{array}$ & $\begin{array}{l}3.53 \% \\
(106)\end{array}$ & $\begin{array}{l}4.89 \% \\
(147)\end{array}$ & $\begin{array}{l}0.43 \% \\
(13)\end{array}$ & $3007(100 \%)$ \\
\hline passive) & $\begin{array}{l}\mathrm{m}+\mathrm{p}^{\mathrm{a}} \\
6.59 \%\end{array}$ & $\begin{array}{l}m+p \\
32.35 \%\end{array}$ & $\begin{array}{l}m+p \\
35.87 \%\end{array}$ & $\begin{array}{l}m+p \\
8.44 \%\end{array}$ & $\begin{array}{l}m+p \\
3.22 \%\end{array}$ & $\begin{array}{l}m+p \\
4.47 \%\end{array}$ & $\begin{array}{l}m+p \\
0.39 \%\end{array}$ & $\begin{array}{l}m+p \\
3292(100 \%)\end{array}$ \\
\hline Passive & & & $\begin{array}{l}(285) \\
100 \%\end{array}$ & & & & & $285(100 \%)$ \\
\hline
\end{tabular}

a $m+p$ : if we add the percentage of middle/mediopassive forms $(m)$ and passive forms $(p)$.

21 For instance, Aorist in Homeric Greek vs. Aorist in Classical Greek: $\chi^{2}=2.008$, p=.156; Aorist in Classical Greek vs. Aorist in Koine Greek: $\chi^{2}=3.018, \mathrm{p}=.082$; Aorist in Homeric Greek vs. Aorist in Koine Greek: $\chi^{2}=.356$, $\mathrm{p}=.551$. 
TABLE 7.10в Tense/Aspect and Voice in Plato (Classical Greek): Percentage of use of the different tenses/aspects with the different voice morphologies

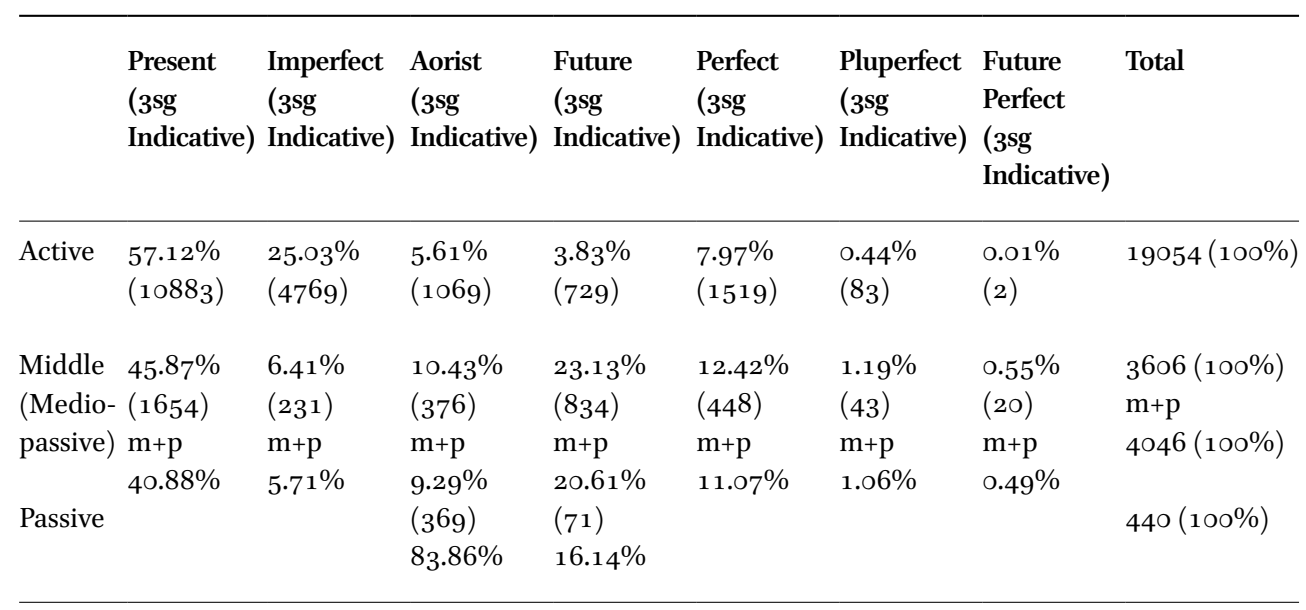

TABLE 7.10C Tense/Aspect and Voice in New Testament (Koine Greek): Percentage of use of the different tenses/aspects with the different voice morphologies

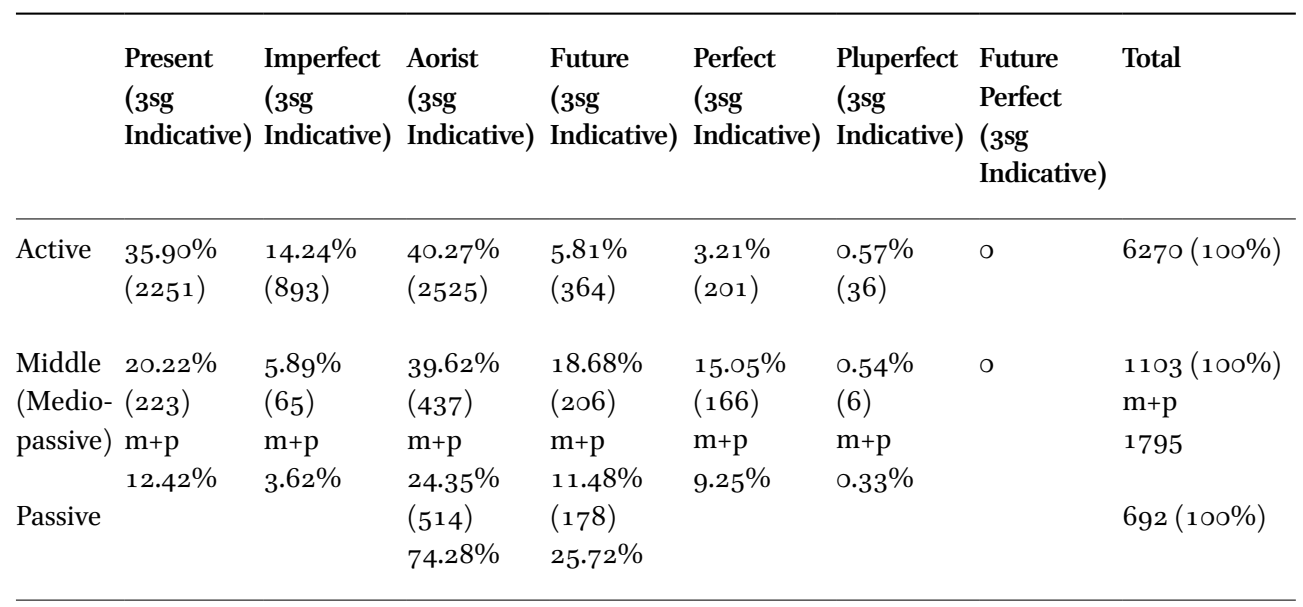


The following changes in Voice in Koine Greek can illustrate the development of the relationship between Voice and Tense/Aspect and the new status of this relationship (which appears in the quantitative data above). From the Koine Greek period, the marking of the autobenefactive interpretation by the mediopassive morphology is lost. ${ }^{22}$ The active and mediopassive transitive forms are used, one next to the other, even in the same sentence, without an essential difference in the interpretation, as is shown in (9).

\section{(9) timômen tòm múrion -timómetha}

estimate:ACT.PRS.1PL ART.ACC numberless:ACC - estimate:MP.PRS.1PL tòn múrion

ART.ACC numberless:ACC

(In both cases, the verb means 'calculate/estimate') (Mayser 1926: 112)

With regard to the middle and passive morphology, which are distinguished only in the Aorist and Future, free alternation is still observed in Koine Greek, but the new element for this period is the extension of the passive morphology. For instance, the following deponents and intransitives have passive Futures and Aorists (instead of middle) in the Roman papyri (Chatzidakis 1892 [1975]: 193-200):

(10) èisthánthēn feel:PASS.AOR.1SG (PMich. 486.7; 2nd c. AD) elupêtthē be.grieved:PASS.AOR.3SG (PMich. 497.15; 2nd c. AD) melēthêis care:PASS.AOR.2SG (PMich. 466.35; 2nd c. AD)

The new tendency for verbs in anticausative constructions in Koine Greek, and mainly in Early Byzantine - after the change in the system of voice marking is completed - is to be marked with active suffixes and not with mediopassive as in Homeric Greek. Hence, the active voice begins to be extended to anticausatives that participate in transitivity alternations. The change concerns only the anticausative morphology (Undergoer + anoígetai open:MP.PRS.3SG $\rightarrow$ Undergoer + anoígei open:ACT.PRS.3SG) without other syntactic changes in the existing alternation, as is shown in (11) below:

22 On the contrary, from Classical Greek onwards, the passive construction becomes more productive (more verbs can appear in a passive construction). Cf. Luraghi (2010: 70): "Passive became increasingly obligatory, and its extension proceeds from prototypically transitive verbs with accusative objects, to verbs with lower degrees of transitivity with non-accusative objects." 
(11) Active transitive
a. eksaí[phnēs] anoígō anugōi toùs
suddenly open:ACT.PRS.1SG open:ACT.PRS.1SG ART.ACC ophthalmoús mou
eyes:ACC 1SG.GEN
'And suddenly I open my eyes.' (UPZ 1.78 rp1)

Active intransitive
b. hoútōs ouk anoígei
tò stóma
autoû
so not open:ACT.PRS.3SG ART.NOM mouth:NOM 3SG.GEN
'So his mouth does not open.' (NT, Act.Ap. 8.32; 1st c. AD)

We have demonstrated an interrelation and a parallelism in the development of Tense/Aspect and Voice in the history of the Greek language, which follows the original relationship (hypothesized for PIE) between Tense/Aspect and Voice. The lexical aspect (Aktionsart) is one of the categories that determine the developments in the verbal system of Homeric Greek and, in particular, is also relevant to several features of Voice. After verbal forms became linked to the (grammatical) aspect in Koine Greek, the encoding of the valencyreducing and valency-increasing derivations through voice endings becomes more regular in Greek verbs, creating a morphological opposition between transitives and intransitives. The active marks the transitive, whereas the mediopassive the intransitive: Transitives (with autobenefactive interpretation) are not marked with mediopassive morphology, whereas the new tendency is for active anticausatives to be marked with active morphology.

\section{4}

\section{Conclusion}

Starting with the hypothesis that the Perfect (Tense/Aspect) and the Middle (Voice) are historically related and that in (standard) Proto-Indo-European a number of innovations resulted in the introduction of some elements of the Perfect-Stative inflection into the Present system (cf. Kulikov \& Lavidas 2013), we have examined the directionality of changes in the domain of Tense/Aspect and Voice in Greek.

We have shown how the original relationship (hypothesized for Proto-IndoEuropean) between Tense/Aspect and Transitivity/Voice determines the direction of changes in Vedic and Greek. We argued that this (hypothesized) initial correlation between Transitivity/Voice and Tense/Aspect (intransitive perfect $\sim$ transitive-causative present formations) is reflected both in Vedic and Greek in the form of some tendencies and relics. Taking as a basis for our study the 
analysis of Vedic active Perfects that are used intransitively and syntactically belong with middle Presents, we have also demonstrated how this relationship depends on the new features acquired by the voice morphology as well as on the development of the categories Tense and Aspect. More specifically, we can conclude that historical evidence from Vedic and Greek gives us good reasons to believe that the original correlation between Tense/Aspect and Transitivity/ Voice determines the direction of further changes in the corresponding domains of the morphological system of these languages: the emergence and expansion of the new productive markers of transitivity oppositions (passive/ active and anticausative/causative) aiming to avoid collapse of the original system of oppositions by replacing the waning category (in our case, 'split causativity'). In other words, the linguistic material from the documented history of Greek, Vedic (and perhaps some other ancient Indo-European languages) furnishes important evidence for the non-arbitrary character (directionality) of certain changes in these domains of the linguistic system.

Furthermore, we have argued that in Homeric Greek, the morphological oppositions traditionally thought of as manifesting the category of Tense show certain relationships with Aktionsart, whereas the middle (mediopassive) voice, presumably originating in the Perfect/Stative part of the paradigm, still remains sensitive to Aktionsart characteristics. We have demonstrated that changes in Voice go parallel with Tense/Aspect developments in Greek: Koine Greek shows an entirely new system of Voice and Tense/Aspect. As verbal forms become linked to the (grammatical) aspect, the relic correlation between Transitivity/Voice and Tense/Aspect disappears, and the distribution of voices follows a common pattern (for all voices) that favors the active morphology, which is now exclusively related to transitives, in cases of transitive alternations, rather than the (aspectual) characteristics of the tenses. This, again, can serve as evidence for the non-random character of historical changes in the linguistic system of Koine Greek, triggered by the original, albeit disappearing, structure of this domain, which still preserves archaic traces of the original category Perfect/Stative that determines a plethora of new trends in the system of encoding of transitivity oppositions.

Altogether, diachronic evidence from the documented history of Greek and Vedic provides us with valuable data for the general theory of historical linguistics and for substantiation of the fundamental claim about the directionality (i.e. non-arbitrary character) of linguistic changes.

\section{Acknowledgements}

This research was supported by a generous research grant awarded to Leonid Kulikov from the European Union's Horizon 2020 research and innovation 
programme under the Marie Skłodowska-Curie grant agreement nr. 665778 and from the NCN (POLONEZ grant nr. 2015/19/P/SH2/O2O28) during a research stay at Adam Mickiewicz University in Poznań.

\section{Abbreviations}

The glosses follow Leipzig Glossing rules. Additionally, the following glosses have been adopted: MP - Mediopassive (non-active); PTC - particle.

\section{References}

Allan, Rutger. 2003. The Middle Voice in Ancient Greek: A Study in Polysemy. Amsterdam: Gieben.

Bader, Françoise. 1972. Parfait et moyen en grec. In: Mélanges de linguistique et de philologie grecque offerts à Pierre Chantraine, [ed. by Françoise Bader], 1-21. Paris: Klincksieck.

Bakker, Egbert J. 1994. Voice, Aspect and Aktionsart: Middle and Passive in Ancient Greek. Voice: Form and Function, ed. by Barbara Fox \& Paul J. Hopper, 23-47. Amsterdam/ Philadelphia: John Benjamins.

Blass, Friedrich, Albert Debrunner \& Friedrich Rehkopf. 1975 [1984]. Grammatik des neutestamentlichen Griechisch. Göttingen: Vandenhoeck \& Ruprecht.

Chantraine, Pierre. 1927. Histoire du parfait grec. Paris: Champion.

Chantraine, Pierre. 1953. Grammaire homérique. II: Syntaxe. Paris: Klincksieck.

Chantraine, Pierre. 1961. Morphologie historique du grec. Paris: Klinksiek.

Chatzidakis, Georgios. N. 1892 [1975]. Einleitung in die neugriechische Grammatik. Leipzig: Breitkopf und Härtel.

Dahl, Eystein. 2010. Time, Tense and Aspect in Early Vedic Grammar: Exploring Inflectional Semantics in the Rigveda. Leiden: Brill.

Delbrück, Berthold. 1888. Altindische Syntax. Halle a. S.: Verlag der Buchhandlung des Waisenhauses.

Delbrück, Berthold. 1897. Vergleichende Syntax der indogermanischen Sprachen. Zweiter Teil. Strassburg: Trübner.

Di Giovine, Paolo. 1990-1996. Studio sul perfetto indoeuropeo, I-III. Roma: Il Calamo.

Gelderen, Elly van. 2004. Grammaticalization as Economy. Amsterdam/ Philadelphia: John Benjamins.

Gotō, Toshifumi. 1997. Überlegungen zum urindogermanischen «Stativ». Berthold Delbrück y la sintaxis indoeuropea hoy: Actas del Coloquio de la Indogermanische Gesellschaft, ed. by Emilio Crespo \& José Luís, 165-192. Madrid: UAM \& Wiesbaden: Reichert.

Grosse, Hermann. 1889. Beiträge zur Syntax des griechischen Mediums und Passivums. Dramburg: Druck von Th. Kämpf. 
Horrocks, Geoffrey. 2007. The Language of Homer. A History of Ancient Greek from the Beginnings to Late Antiquity, ed. by Anastassios-Fivos Christidis, $475^{-487}$. Cambridge: Cambridge University Press.

Humbert, Jean. 1945. Syntaxe Grecque. Paris: Librairie Klincksieck.

Jankuhn, Harald. 1969. Die passive Bedeutung medialer Formen untersucht an der Sprache Homers (KZ; Ergänzungsheft 21). Göttingen: Vandenhoeck \& Ruprecht.

Jasanoff, Jay. 1978. Stative and Middle in Indo-European (IBS 23). Innsbruck: Institut für Sprachwissenschaft der Universität Innsbruck.

Kortlandt, Frederik H. H. 1979. Toward a Reconstruction of the Balto-Slavic Verbal System. Lingua 49: 51-70.

Kortlandt, Frederik H. H. 1981. 1st sg. Middle ${ }^{*}-\mathrm{H}_{2}$. Indogermanische Forschungen 86: $123^{-136 .}$

Kortlandt, Frederik H. H. 20o9. Baltica \& Balto-Slavica. Amsterdam: Rodopi.

Kortlandt, Frederik H. H. 2010. An Outline of Proto-Indo-European. Studies in Germanic, Indo-European and Indo-Uralic, ed. by Frederik H. H. Kortlandt, 37-45. Amsterdam: Rodopi.

Kulikov, Leonid. 1999. Split Causativity: Remarks on Correlations Between Transitivity, Aspect, and Tense. Tense/Aspect, Transitivity and Causativity: Essays in Honour of Vladimir Nedjalkov, ed. by Werner Abraham \& Leonid Kulikov, 21-42. Amsterdam/ Philadelphia: John Benjamins.

Kulikov, Leonid. 2005. Reduplication in the Vedic Verb: Indo-European Inheritance, Analogy and Iconicity. Studies on Reduplication, ed. by Bernard Hurch, 431-454. Berlin: Mouton.

Kulikov, Leonid. 20o6. Passive and Middle in Indo-European: Reconstructing the Early Vedic Passive Paradigm. Passivization and Typology: Form and Function, ed. by Werner Abraham \& Larisa Leisiö, 62-81. Amsterdam/Philadelphia:John Benjamins.

Kulikov, Leonid \& Nikolaos Lavidas. 2013. Reconstructing Passive and Voice in ProtoIndo-European. Proto-Indo-European Syntax and its Development. (Journal of Historical Linguistics 3.1: Special issue, ed. by Leonid Kulikov \& Nikolaos Lavidas), 98-121.

Kulikov, Leonid \& Lavidas, Nikolaos. 2017. Between Passive and Middle: Voice and Verbal Classes in Greek and Vedic. Contrastive Studies in Verbal Valency, ed. by L. Hellan, A. L. Malchukov \& M. Cennamo, 298-325. Amsterdam: John Benjamins.

Kümmel, Martin. 1996. Stativ und Passivaorist im Indoiranischen (HS; Erganzungsheft 39). Göttingen: Vandenhoeck \& Ruprecht.

Kümmel, Martin. 200o. Das Perfekt im Indoiranischen. Wiesbaden: Reichert.

Kuryłowicz, Jerzy. 1932. Les désinences moyennes de l'indo-européen et du hittite. Bulletin de la Société de Linguistique de Paris 30(1): 1-4.

Kuryłowicz, Jerzy. 1964. The Inflectional Categories of Indo-European. Heidelberg: C. Winter.

Latacz, Joachim (ed.). 2003. Homers Ilias: Gesamtkommentar. Munich/Leipzig: K. G. Saur. Lavidas, Nikolaos. 2012. Passives in the History of Greek: Evidence for the Role of the Passive Suffix. Folia Linguistica Historica 33(1): 87-122. 
Lavidas, Nikolaos \& Dimitra Papangeli. 2006. Deponency in the Diachrony of Greek. Deponency and Morphological Mismatches, ed. by Matthew Baerman, Greville G. Corbett, Dunstan Brown \& Andrew Hippisley, 97-126. Oxford: Oxford University Press.

Lavidas, Nikolaos, Georgia Fotiadou \& Ianthi Maria Tsimpli. 2012. Active vs. Nonactive Voice in the Greek Diachrony: Real or Apparent Optionality in the Use of Voice Morphology; Selected Papers of the 1oth ICGL, ed. by Zoe Gavriilidou, Angeliki Efthymiou, Evangelia Thomadaki \& Penelope Kambakis-Vougiouklis, 390-40o. Komotini: Democritus University of Thrace.

Luraghi, Silvia. 2010. The Extension of the Passive Construction in Ancient Greek. Acta Linguistica Hafniensia 42(1): 6o-74.

Luraghi, Silvia, Anna Pompei \& Stavros Skopeteas. 2005. Ancient Greek. Munich: Lincom Europa.

Mayser, Edwin. 1926. Grammatik der griechischen Papyri aus der Ptolemäerzeit. II. Satzlehere 1. Analytischer Teil. Berlin/ Leipzig: Walter de Gruyter.

Monro, David Binning. 1891. A grammar of the Homeric dialect (2nd edn.). Oxford.

Moser, Amalia. 1988. The History of Perfect Periphrases in Greek. PhD Dissertation, University of Cambridge.

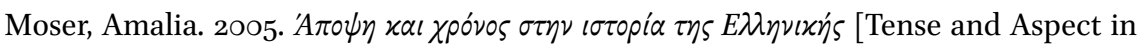
the History of Greek]. Parousia: National and Kapodistrian University of Athens.

Moser, Amalia. 2008. The Changing Relationship of Tense and Aspect in the History of Greek. STUF-Sprachtypologie und Universalienforschung 61(1):5-18.

Moser, Amalia. 2014. From Aktionsart to Aspect: Grammaticalization and Subjectification in Greek. Acta Linguistica Hafniensia 46(1): 64-84.

Napoli, Maria. 2006. Aspect and Actionality in Homeric Greek: A Contrastive Analysis. Milano: Francoangeli.

Oettinger, Norbert. 1976. Der indogermanische Stativ. Münchener Studien für Sprachwissenschaft 34: 109-149.

Renou, Louis. 1925. La valeur du parfait dans les hymnes védiques (Collection linguistique 18). Paris: Champion.

Schwyzer, Eduard \& Albert Debrunner. 1950. Griechische Grammatik: Zweiter Band; Syntax und syntaktische Stilistik (Handbuch der Altertumswissenschaft, 2. Abt., 1. Teil, 2. Bd.). Munich: C. H. Beck.

Sihler, Andrew L. 1995. New Comparative Grammar of Greek and Latin. Oxford: Oxford University Press.

Stang, Christian S. 1932. Perfektum und Medium. Norsk Tidsskrift for Sprogvidenskap 6: 29-39.

Velten, Hermann V. 1931. On the Origin of the Categories of Voice and Aspect. Language 7(4): 229-241.

Wackernagel, Jacob. 1904. Studien zum griechischen Perfectum. Programm zur akademischen Preisverteilung, Göttingen, 3-24 [Reprinted in J. Wackernagel, Kleine Schriften. Göttingen: Vandenhoek and Ruprecht, 1953, 1000-1021]. 